\title{
O Pavićevu i Markovićevu prijevodu Aristotelove definicije tragedije
}

Bojan Marotti*

bojan.marotti@zg.t-com.hr

https://orcid.org/0000-0002-0470-3569 https://doi.org/10.31192/np.19.3.7

UDK: 1 Aristoteles

$82-21$

80Pavić, A.

1Marković, F.

Izvorni znanstveni rad / Original scientific paper

Primljeno: 31. ožujka 2021.

Prihvaćeno: 24. svibnja 2021.

Znamenita Aristotelova definicija tragedije u povijesti je hrvatske filozofije $i$ (klasične) filologije prevođena razmjerno često. Može se govoriti o desetak pokušaja, uzmu li se u obzir, osim cjelovitih prijevoda Aristotelove Poetike, i različita druga djela, kao što su povijesti (grčke) filozofije, ili povijesti književnih teorija $i$ estetike. U prilogu se uspoređuju prijevodi Armina Pavića i Franje pl. Markovića. Pri tome se razmatra i odabir hrvatskih otpovjednica pri prijenosu pojedinih (temeljnih) pojmova iz grčkoga jezika u hrvatski i cjelina stavka, budući da jedno $i$ drugo, naime odabrane prevedenice i sam »ustroj « hrvatske rečenice, redovito uрис́uju i na (prevoditeljevo) poimanje Aristotelova shvaćanja tragedije, ali $k$ tomu i na razumijevanje Aristotelove filozofije umjetnosti u cjelini.

Ključne riječi: Aristotelova definicija tragedije, (filozofsko) nazivlje, Franjo Marković, Armin Pavić, tragedija.

\section{Uvod $^{1}$}

Jedan od najznamenitijih stavaka u cjelokupnoj povijesti estetike, pa i filozofije općenito, a neki ga drže i najznamenitijom definicijom $» u$ čitavoj povijesti ljudskoga duha «, ${ }^{2}$ Aristotelova definicija, ili - kako bi rekao Franjo pl. Marković - određaj tragedije, u povijesti je hrvatske filozofije i (klasične) filologije prevođen razmjerno često. Može se govoriti o desetak pokušaja, uzmu li se u

\footnotetext{
* Dr. sc. Bojan Marotti, Hrvatska akademija znanosti i umjetnosti, Zavod za povijest i filozofiju znanosti; Ante Kovačića 5, HR-10000 Zagreb.

1 Ovaj je rad financirala Hrvatska zaklada za znanost projektom IP-2016-06-6762.

${ }^{2}$ Usp. ARISTOTEL, O pjesničkom umijeću, preveo i komentarima popratio Zdeslav Dukat, Književna smotra, 10 (1978) 31-32, 3-22, navodak na str. 13, bilj. 29; također ARISTOTEL, O pjesničkom umijeću, prijevod i objašnjenja Zdeslav Dukat, Zagreb, August Cesarec, 1983, 109, bilj. 229.
} 
obzir, osim cjelovitih prijevoda Aristotelove Poetike (Pavić, ${ }^{3}$ Kuzmić, ${ }^{4}$ Dukat), i pojedine povijesti (grčke) filozofije (npr. Bazala, Šanc), ${ }^{5}$ potom estetike (poput Markovićeve), ili pak različite povijesti književnih teorija, teatrološke ili dramaturške rasprave (poput Švacovljeve Antičke dramaturgije), ${ }^{6}$ gdje se u prikazima Aristotelove filozofije umjetnosti redovito razmatra i taj određaj, a nerijetko se donosi i njegov prijevod (više ili manje cjelovit).

Taj su dakle preslavni stavak preveli i Armin Pavić i Franjo pl. Marković. Njihovi se životi i inače dodiruju i neobično isprepleću. Pripadaju zapravo istomu naraštaju, iako je Marković godinu dana mlađi: Pavić je rođen 1844. (29. ožujka, u Požegi), a Marković 1845. (26. srpnja, u Križevcima). Obojica su studirali klasičnu filologiju i slavistiku u Beču, Marković k tomu još i filozofiju. Pavić je studij završio 1864., a Marković 1865. (filozofiju je doktorirao 1872. kod Roberta Zimmermanna). Pavić je postao profesorom hrvatskoga jezika i književnosti na Filozofskome fakultetu u Zagrebu godine 1877., a Marković profesorom filozofije odmah nakon obnove Sveučilišta 1874. Obojica su bili rektori Sveučilišta: Marković već godine 1881., a Pavić istom 1896., petnaest godina poslije. No Pavić je pravim članom Akademije postao 1874., dakle dvije godine prije Markovića, koji je u Akademiju primljen 1876. Obojica su bili i saborski zastupnici. Napokon, umrli su iste godine, 1914., Pavić sedam mjeseci prije, 12. veljače, a Marković 15. rujna. Pavić nije doživio Prvi svjetski rat, a Marković jest.

\section{Međusobni sukobi}

Započeli su surađivati kao vrlo mladi, ubrzo nakon studija, godine 1869., kada je Pavić imao 25, a Marković 24 godine. Naime ponudili su uredništvu Vienca da zajednički pišu rubriku pod naslovom Naše kazalište, što je uredništvo prihvatilo. Ta se je njihova rubrika pojavila već u prvome broju (prvoga godišta)

\footnotetext{
${ }^{3}$ Vidi Aristotelova poetika, sa grčkoga na hrvatski preveo i protumačio Armin Pavić, Zagreb, Štamparna Dragutina Albrehta, 1869.

${ }^{4}$ Vidi Aristotelova poetika, izdao i preveo Martin Kuzmić, Zagreb, Tisak Dioničke tiskare, 1902, te potom Aristotelova Poetika, s prijevodom i komentarom izdao Martin Kuzmić, Zagreb, Tisak kr. zemaljske tiskare, 1912. Usp. i pretisak potonjega izdanja: Zagreb, Studentski centar Sveučilišta u Zagrebu, 1977.

${ }^{5}$ Vidi Albert BAZALA, Povjest filozofije, sv. 1. Povjest narodne filozofije grčke, Zagreb, Izdala »Matica hrvatska«, 1906., te Franjo ŠANC, Povijest filozofije, sv. 1. Filozofija starih Grka $i$ Rimljana, Zagreb, Izdaje Knjižnica Života, 1942.

${ }^{6}$ Vidi Vladan ŠVACOV, Antička dramaturgija. Antropografija antičke drame, priredio, sastavio popis djela i režija Vladana Švacova, te pogovor napisao Bojan Marotti, predgovor Sibila Petlevski, Zagreb, Artresor naklada, 2014.
} 
od »23. siečnja«1869. No taj prvi prilog nije potpisao i Franjo Marković, premda u uvodnome dijelu toga prvoga priloga Armin Pavić kaže ovako:?

»Moj prijatelj, naš pjesnik Franjo Marković razgovarao se je sa mnom ovih dana o toj stvari i mi se ponudismo redakciji 'Vienca', da bismo bili spremni po mogućnosti naših sila u njenom časopisu toj kazalištnoj potrebi doskočiti, a ona nam evo ovu rubriku u tu svrhu ustupi.«

Važno je uočiti da Pavić kaže upravo »moj prijatelj«, što je, reklo bi se, znakovito, jer to »prijateljstvo «nije potrajalo. Zajednički su pisali još do 3. travnja, tj. do broja $11 .{ }^{8}$ Zatim je uslijedila manja stanka, a u broju 15. (od 1. svibnja) nastavio je sam Pavić. ${ }^{9}$ Pri tome je odmah na početku oštro prigovorio Markoviću: ${ }^{10}$

»Kako sam u uvodu k ovim člankom spomenuo, bio je samnom dogovorio moj prijatelj, da zajednički radimo. Mi i zbilja isprvice tako činjasmo, te se svjetovasmo što i kako ćemo. Nu doskora ostade sav posao na meni, što si držim za dužnost spomenuti [...].»

A potom kaže da će ubuduće tako i nastaviti. No zatim je napisao svega još jedan nastavak, ovaj put nakon podulje stanke, u broju 32. (od 28. kolovoza), u kojem se je obrušio na novi kazališni odbor. ${ }^{11}$ A nakon toga nastavio je pisati sam Marković, počevši od broja 38. (od 9. listopada). ${ }^{12}$

Prema tome, kako je već rečeno, »idila« nije dugo potrajala. Surađivali su dakle, »kao prijatelji«, oko dva i pol mjeseca. A zatim se nižu različiti sukobi. Katkada i prilično žestoki. Primjerice, u poznatoj polemici o Gundulićevu Osmanu u svojoj raspravi Estetična ocjena Gundulićeva Osmana, od godine 1879., odgovarajući na Estetičku ocjenu Gundulićeva Osmana, koju je Marko-

\footnotetext{
7 Vidi Armin PAVIĆ, Naše kazalište, Vienac, 1 (1869) 1, 12-15. Zapravo, Pavić je potpisao samo prvi dio toga prvoga priloga (12-13, gdje se nalazi i navedeni ulomak; potpis je na 13. stranici). Preostali bi dio dakle trebalo smatrati zajedničkim (13-15, nakon potpisa). U tzv. »živoj glavi« piše »A. Pavić: Naše kazalište. « posvuda, tj. na 12., 13. i 14. stranici, a na 15. je već naveden naslov idućega članka, koji počinje u desnome stupcu te 15. stranice (takav je bio običaj u Viencu). No od 2. broja, premda rubrika nije potpisana, nalazimo u »živoj glavi« redovito »F. Marković i A. Pavić: Naše kazalište.« (vidi npr. 42. stranicu). Činjenica da ta rubrika i nadalje nije potpisana, a da je u 1. broju ipak naveden Armin Pavić, razlogom je da se u bibliografijama obično navodi samo Pavić kao pisac svih priloga.

${ }^{8}$ Vidi Vienac, 1 (1869), 11, 222-224. Taj je prilog označen kao 8. nastavak, ali zapravo tih zajedničkih priloga ima 9, jer su 3. prilog računali kao jedan, premda je razdijeljen u dva dijela, tj. na dva broja: početak mu je u broju 4. od 13. veljače, a »konac « u broju 5. od 20. veljače. Vidi Vienac, 1 (1869) 4, 89-93; 5, 112-114.

9 Vidi Vienac, 1 (1869), 15, 281-285. Tu je doista i potpisan samo Pavić, a i u »živoj glavi« piše »A. Pavić: Naše kazalište.«.

${ }^{10}$ Vidi Vienac, 1 (1869) 15, 281.

${ }^{11}$ Vidi Vienac, 1 (1869) 32, 552-555.

${ }^{12}$ Vidi Vienac, 1 (1869) 38, 653-655. To bi bio 11. nastavak, kojemu je završetak u idućem broju (39, 671-672). U »živoj glavi« sada piše »Fr. M.: Naše kazalište«.
} 
vić čitao »13. siečnja 1877.« u Akademiji, ${ }^{13}$ Pavić na jednome mjestu ustvrđuje sljedeće: ${ }^{14}$

»G. M. ima doista mnogo dobre volje, da bi me u svom pisanju publici prikazao, kao da sam sada ili prije kada šenuo duhom, ali dokazivanje ga. Ma. nije ni po što na 'povodu objektivnih nedvojbenih podkrepa', nego je u povodu sve samih sofizama, u kojih nema ni za lijek sofije.«

Nekako je u isto vrijeme izbio još jedan sukob, i to oko pravopisa. Naime i Pavić i Marković bili su članovi tzv. pravopisnoga pododbora, koji je osnovan početkom 1877. da bi se riješio tadašnji "pravopisni nered « u školama. Osim njih, u tome su pododboru još bili Franjo Petračić, Tadija Smičiklas i Ljudevit Modec, a predsjednik mu je bio Adolfo Veber. Naime, vlada je 1877. postavila zemaljskomu školskomu odboru (kojemu je predsjednik bio Ivan Kukuljević) sljedeća tri pitanja: $:^{15}$

»1. drži li odbor, da bi se pravopisnomu neredu, zavladavšemu u pučkih i srednjih školah ove zemlje na put stati imalo? 2. na koji bi se način to postići imalo? 3. da li je propisanje jedinstvenoga školskoga pravopisa moguće, i koj bi imao biti taj pravopis? «16

Spomenuti je pododbor zasjedao početkom te 1877., dakle u vrijeme kada je Marković čitao svoju raspravu o Gundulićevu Osmanu u Akademiji, a u ožujku je te iste godine podnio zemaljskomu školskomu odboru izvješće, ${ }^{17} \mathrm{u}$ kojem je potanko opisao pravopisna pravila na kojima bi valjalo izraditi (novi) pravopis, uz preporuku da se sve to i objavi u jednoj knjizi. ${ }^{18}$ Među ostalim, raspravljalo se je i o pravopisnome načelu. Većina je članova bila za tvorbeni, morfonološki, ili kako se je tada govorilo (umjereni) »etimologički« pravopis. Zapravo svi, osim Armina Pavića, koji se je od toga ogradio, sukobivši se pri tome izravno

${ }^{13} \mathrm{Tu}$ je raspravu Marković objavio u četiri dijela u Radu JAZU i to knj. 46, 1879, 78-165, knj. 47, 1879, 129-221, knj. 50, 1879, 96-175 i knj. 52, 1880, 1-140 te kao knjigu: Franjo MARKOVIĆ, Estetička ocjena Gundulićeva Osmana, Zagreb, Tisak Dioničke tiskare, 1880.

${ }^{14}$ Vidi Armin PAVIĆ, Estetična ocjena Gundulićeva Osmana, Zagreb, Tiskarski i litografički zavod C. Albrechta, 1879, 5. O Pavićevu životu i radu vidi nekrolog Đure KÖRBLERA u Ljetopisu JAZU za godinu 1913. (sv. 28, 1914, 87-119).

${ }^{15}$ Vidi o tome potanje Zlatko VINCE, Putovima hrvatskoga književnog jezika, Zagreb, SNL, 1978, 584-585, te Mirko PETRAVIĆ, Jedna značajna obljetnica, Jezik, 1 (1952-1953) 5, 156160 (članak je objavljen u prigodi sedamdeset i pete obljetnice rada zemaljskoga školskoga odbora i osnivanja pravopisnoga pododbora). Usp. k tomu Bojan MAROTTI, Dativ, lokativ i instrumental množine u pripovijetkama Stjepana Zlatovića. Prinos razumijevanju pojma književnoga jezika, u: Pavao KNEZOVIĆ (gl. ur.), Zbornik o Stjepanu Zlatoviću, Zagreb, Hrvatski studiji Sveučilišta u Zagrebu, 2008, 95-162, posebice poglavlje pod naslovom Hrvatski književni jezik između 1877. i 1892., 102-104.

${ }^{16}$ Usp. Ladislav MRAZOVIĆ, Ob ustanovi hrvatskoga pravopisa, Vienac, 9 (1877) 11, 176-179, posebice 178.

${ }^{17}$ Vidi spomenutu Vinceovu knjigu Putovima hrvatskoga književnog jezika..., 585-586.

${ }^{18} \mathrm{O}$ tome je u Viencu godine 1877. izvijestio već spomenuti Ladislav Mrazović. Vidi Mrazović, Ob ustanovi hrvatskoga pravopisa, Vienac, 9 (1877) 11, 176-179; 9 (1877) 13, 210-211; 9 (1877) $14,217-221$. 
s Markovićem. Štoviše, Pavić je izjavio da će u zemaljskome školskome vijeću braniti pravopis prema izgovornome načelu, fonološki, ili »fonetički«. Zemaljski je odbor izvješće proslijedio vladi. Vlada međutim nije postavila zahtjev za izradom pravopisnoga priručnika. To je istom učinila 1889., iste godine kada je umro Adolfo Veber, povjerivši izradu pravopisa Ivanu Brozu, i to prema izgovornome načelu, dakle onako kako je to predlagao Pavić, koji je te 1877. bio u izrazitoj manjini. I taj se je pravopis pojavio 1892. To je to razdoblje od petnaest godina, od 1877. do 1892., u kojem se je pripremala i odvijala »zamjena (uzornoga) sustava.$^{19}$

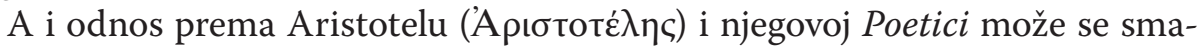
trati nekom vrstom sukoba, makar prikrivenoga, ako je suditi prema onome što Pavić kaže na početku spomenute rasprave Estetična ocjena Gundulićeva Osmana, gdje najprije podsjeća čitatelja na to da je četrnaest dana nakon što je Marković čitao svoju raspravu, dakle 27. siječnja 1877., on sam dobio priliku govoriti u Akademiji, pa veli ovako: ${ }^{20}$

»Tom zgodom se poslužih, pak s nekoliko riječi razložih gu. Mu., kako mu je sa svijem neskladno ono njegovo poregjivanje Danta s Gundulićem, i kako je ali sa svijem krivo razumio podpunoma jasne, vrlo znamenite Aristotelove riječi.»

(Primijetiti je usput da je sljednik jata u dugim slogovima, kao i u prijevodu Poetike, pisan troslovom ije, dakle vukovski.)

\section{Određaj tragedije}

I doista, usporedi li se Pavićev prijevod Aristotelova određaja tragedije s onim Markovićevim, stječe se dojam kao da je Marković upravo namjerno prevodio drugačije. Naravno, kada je razliku mogao provesti. Dakako, Markovićev prijevod nije nastao istom 1903., kada je njegov Razvoj i sustav obćenite estetike objelodanjen, ${ }^{21}$ nego znatno prije, budući da je Marković estetiku, ili srodne predmete, »ciklički« predavao od 1874., tj. od jeseni one godine kada ga je, 27. travnja, car Franjo Josip I. imenovao prvim »redovitim javnim profesorom za filozofiju teoretičku i praktičku i za poviest filozofije« na Mudroslovnome fa-

\footnotetext{
${ }^{19} \mathrm{O}$ tome sam pisao na više mjesta, ali usp. Marotti, Dativ, lokativ i instrumental množine u pripovijetkama Stjepana Zlatovića. Prinos razumijevanju pojma književnoga jezika, u: Knezović (gl. ur.), Zbornik o Stjepanu Zlatoviću..., posebice poglavlje pod naslovom Pisati u razdoblju promjene književnoga jezika, 115-118. O posljedicama te »zamjene« vidi Bojan MAROTTI, Je li Vidrić doista pisao »jugoslovenskim esperantom«?, Kolo, 19 (2010) 1-2, 124-151.

${ }^{20}$ Vidi Pavić, Estetična ocjena Gundulićeva Osmana..., 3.

${ }^{21}$ Vidi Franjo MARKOVIĆ, Razvoj i sustav obćenite estetike, Zagreb, Nakladom kr. hrv.-slav.dalm. zemaljske vlade, 1903. (pretisak: Split, Izdavačka radna organizacija LOGOS, 1981).
} 
kultetu Sveučilišta u Zagrebu, ${ }^{22}$ pa sve do 1913., godinu dana prije smrti, dakle gotovo 40 godina.

Predmeti koje je Marković u tome razdoblju predavao, bili su primjerice sljedeći: Estetika (1874./1875., 1878./1879., 1881./1882., 1884./1885., 1885./1886., 1887./1888., 1891./1892., 1895./1896., 1896./1897., 1899./1900., 1900./1901., 1904./1905.), Estetičke vježbe (1882./1883., 1885./1886., 1888./1889., 1895./1896., 1896./1897., 1897./1898., 1900./1901., 1907./1908., 1908./1909., 1909./1910.), Estetička ocjena Gundulićeva Osmana (1875./1876.), Estetična ocjena najznamenitijih talijanskih tragedija (1877./1878.), Izabrane česti iz poetike (1899./1900.), Psihologija prema estetici (1905./1906.), Estetičko razmatranje Ilijade i Odiseje (1906./1907.), Pregled likovnih umjetnosti (1910./1911.) itd. ${ }^{23}$

No evo grčkoga izvornika Aristotelova određaja tragedije i dvaju spomenutih prijevoda:

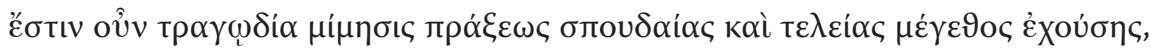

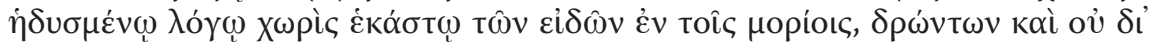

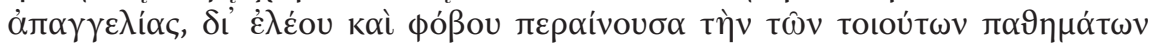
кó $9 \alpha \rho \sigma \mathrm{t} .^{24}$

Tragedija dakle jest vrst pjesničtva, koja govorom punim ukrasa, od kojih se svaka vrst u pojedinim njenim dijelovima posebice uzima i sredstvom činećih a ne pripoviješću, čin dostojan i potpun, imajući neku veličinu, tako oponaša, da pobugjujuć sažaljivanje i strah, čišćenje tih afekta postigava. ${ }^{25}$

»Tragedija je priličba radnje ozbiljne i dovršene, ukrašenim govorom, tako da svaka izmedju vrsti ukrasa rabi samo u po jednom dielu tragedije (to će reći

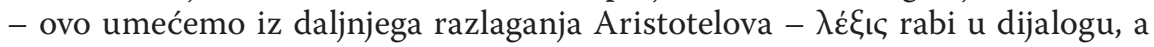
$\mu \varepsilon \dot{\varepsilon}$ oc u koru), i to priličba djelujućih, a ne pripoviedajućim načinom, postižući samilostju i strahom pročistbu tih (takovih) čuvstava. [...]. «16 $^{26}$

Pogledamo li primjerice četiri ključne riječi, ključne ne samo za određaj tragedije nego i za razumijevanje Poetike u cjelini, odmah će se pokazati sva razlika između Armina Pavića i Franje pl. Markovića:

\begin{tabular}{|c|c|c|}
\hline GRČKI NAZIVAK & PAVIĆ & MARIKOVIĆ \\
\hline$\mu \prime \mu \eta \sigma ı \varsigma$ & oponašanje & priličba (paličba) \\
\hline$\pi \rho \hat{\alpha} \xi ı \varsigma$ & čin & radnja \\
\hline 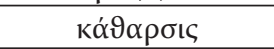 & čišćenje & pročistba \\
\hline$\pi \alpha \dot{\theta} \eta \eta \mu \alpha$ & afekt & čuvstvo \\
\hline
\end{tabular}

${ }^{22}$ Vidi o tome potanje Ivan PEKLIĆ, Život i djelo Franje Markovića, Zagreb - Križevci, Hrvatska akademija znanosti i umjetnosti - Zavod za znanstveno-istraživački rad Koprivničkokriževačke županije u Križevcima, 2014, 48. Usp. i Bojan MAROTTI, Markovićeva kritika Hegelove logike, Rad HAZU, knj. 539, 2019, 33-96, posebice 41.

${ }^{23}$ Navodim prema spomenutoj Peklićevoj knjizi Život i djelo Franje Markovića..., 49-54.

${ }^{24}$ 'A translated and with critical notes by S. H. Butcher, with a prefatory essay »Aristotelian Literary Criticism « by John Gassner, $4^{\text {th }}$ ed., Mineola, New York, Dover Publications, 1951, 22.

${ }^{25}$ Aristotel, Poetika, prev. Armin Pavić, 1869, 30-31.

${ }^{26}$ Marković, Razvoj i sustav obćenite estetike..., 1903, 95. 
Jedno od temeljnih obilježja Zagrebačke filološke škole, kojoj je dakle pripadao i Marković, nešto što se može uočiti na »prvi pogled «, jest tvorba odglagolnih, tzv. radnih imenica dometkom - $b a$. Tako Marković za $\mu$ í

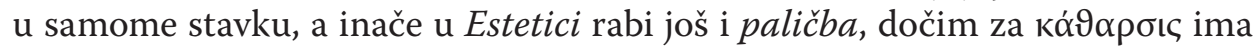
pročistba. Navodim sve u Markovićevu zapisu, tj. prema tvorbenome pravopisu. Danas bi, u zapisu prema izgovornome načelu, bilo prilidžba i palidžba, jer se prilagodba po zvučnosti, koja je inače na izgovornoj razini pretkažljiva, ujedno i zapisuje. Predmetak pa-u glagolu palićiti, pàličím (prema líčiti, lîčím 'praviti', 'tvoriti', u vezi s imenicom likk, likka, dakle 'činiti lik'; naglasni bi uzor bio gráditi, grâdim, izgráditi, izgrādìm) odgovara značenju toga predmetka u glagolu patvòriti (prema tvòriti). $\mathrm{O}$ tome predmetku u Akademijinu rječniku Tomo Maretić veli ovako: ${ }^{27} » P A$, prijedlog, koji se ne nalazi u samostalnoj porabi, već samo u složenicama [...]. Značenje je takovim složenicama, da je nešto drukčije ili drugi put načińeno ili da nije prâvô, da je promijeńeno, rđavo.« A što se tiče glagola prilićiti, priliččm, zanimljivo je da i Kuzmić u Komentaru uza svoj prijevod 1912. veli da glagol $\mu \mu \varepsilon \varepsilon o \mu \alpha ı$ (infinitiv $\mu \iota \mu \varepsilon \hat{\sigma} 9 \alpha \mathrm{l}$ ) zapravo znači 'prema liku činiti priliku', dakle 'priličiti', ${ }^{28}$ premda $\mu$ í $\mu \eta \sigma ı \varsigma$ sam prevodi, kao i Pavić, riječju oponašanje. Slično postupa i Bazala.

Posebno treba obratiti pozornost na različito prevedenu svezu $\mu$ í $\mu$ ¡ıৎ $\pi \rho \alpha ́ \xi \varepsilon \omega \varsigma$. Marković tu grčku svezu prevodi hrvatskom svezom, tj. "priličba radnje «, držeći se time prevoditeljskoga načela »isto istim, različito različitim«, dočim Pavić navedenu svezu prevodi »opisno«, tj. »čin [...] tako oponaša«. Da bi takav prijevod bio jasniji, Pavić uvodi poseban, nov (imenski) prirok »vrst pjesničtva«, tj. »tragedija dakle jest vrst pjesničtva«, čega nema u izvorniku. Takav postupak, da se u prijevod unosi nešto čega u izvorniku nema, zato da bi, recimo, bio jasniji, ili razumljiviji, nije bio uobičajen u Zagrebačkoj školi. Pristaše Zagrebačke škole redovito su hrvatski nastojali približiti, ili »prilagoditi«, izvorniku (ovdje grčkomu jeziku), a ne obrnuto. To je ono što se je poslije uobičajilo nazivati »doslovnim«, ili makar »doslovnijim« prijevodom, jer i takvi prijevodi mogu imati svoje »stupnjevanje«. Skrajnji bi oblik takva doslovnoga prijevoda bio potpuni »odslik«, ili »odljev«, (grčkoga) izvornika u hrvatskome.

\footnotetext{
${ }^{27}$ Vidi Rječnik hrvatskoga ili srpskoga jezika, na svijet izdaje Jugoslavenska akademija znanosti i umjetnosti, sv. IX, 544. Ukupno su objavljena XXIII sv.: Jugoslavenska akademija znanosti i umjetnosti, Zagreb, 1880-1976.

${ }^{28}$ Vidi Aristotelova Poetika, s prijevodom i komentarom izdao Martin Kuzmić, 76. Parčić pak za priličiti ima somigliare, za priličje - immagine i ritratto, a za priličnost - somiglianza, dočim za oponašati navodi contraffare (dakle 'krivotvoriti'), a za oponašati koga veli berteggiare (dakle 'rugati se komu', 'ismijavati koga'). Vidi Dragutin PARČIĆ, Vocabolario croato-italiano, terza edizione corretta ed aumentata, Zara, Tipografia editrice »Narodni List«, 1901, 778 i 592 (pretisak: ArTresor studio, Zagreb, 1995.). Usp. i Bojan MAROTTI, Poimanje tragedije iz duha hamartije, u: Švacov, Antička dramaturgija. Antropografija antičke drame..., 405-466, posebice 423.
} 
Tomu je u svojim prijevodima, kako s akadskoga, tako i s drugih jezika, poput mađarskoga ili grčkoga recimo, težio pokojni profesor Bulcsú László. ${ }^{29}$

S time je u vezi i zâsada koju su beziznimno njegovali pristaše Zagrebačke škole, da naime »sve valja prevesti«, tj. na hrvatski (uključujući i nazivlje određene struke). Upravo je Franjo pl. Marković, uz Bogoslava Šuleka i Dragutina Parčića, najbolji primjer za takav pristup. Uočiti je međutim Pavićev prijevod,

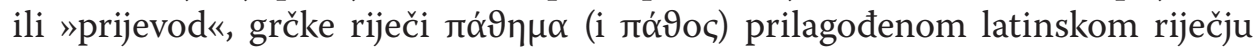
afekt (prema affectus). To je taj suprotan, ali prilično čest postupak, o vrijednosti kojega se može raspravljati (slično postupa i Dukat kada primjerice imenicu $\mu \hat{v} \vartheta o c$ »prevodi « riječju fabula). ${ }^{30}$

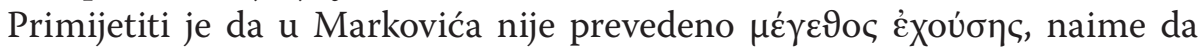
je posrijedi radnja ( $\pi \rho \hat{\alpha} \xi ı \varsigma)$ koja ima veličinu (tj. stanovitu veličinu, reklo bi se slobodnije, primjerenu veličinu, ili - ako se hoće - "pravu« veličinu). Bit će da je riječ o propustu, ili o nedovoljno strogome navođenju, budući da Marković u Estetici, nakon navedenoga određaja, raspravlja o tome što znači jedinstvo radnje, njezina završenost i cjelovitost. ${ }^{31}$ Ako bismo htjeli »markovićevski« pre-

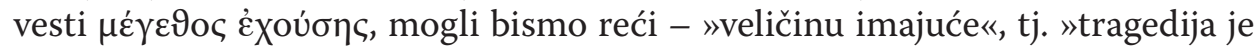
priličba radnje ozbiljne i dovršene, veličinu imajuće, ukrašenim govorom [...]«.

Takav nas (mogući) prijevod dovodi do pitanja mogu li se u hrvatskome sklanjati tzv. glagolni prilozi (sadašnji i prošli). Kao što je poznato, hrvatski su vukovci (npr. Tomo Maretić) propisivali da se ne smiju sklanjati, jer da su prilozi (i tako je ostalo do danas). Stoga sam i ja najprije particip prezenta

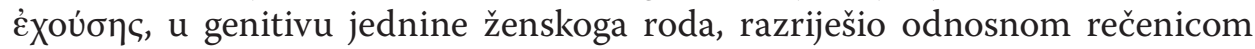
(kako je uobičajeno), pa sam preveo »radnja koja ima veličinu«. No Zagrebačka je škola dopuštala sklonidbu tih tzv. "priloga«, koji u tome slučaju dakako i nisu prilozi, nego (pravi) participi, ili dionici, kako ih je zvao Antun Mažuranić. Stoga Marković ima »djelujućih « za $\delta \rho \omega ́ v \tau \omega v$ i »pripoviedajućim načinom« za

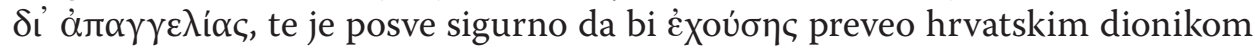
nesvršenim (u genitivu jednine ženskoga roda). Jer i to je jedna potvrda onoga

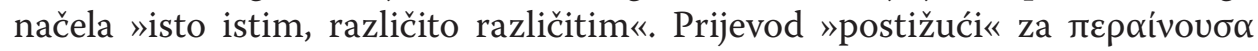
pravi je (glagolni) prilog.

Zanimljivo je međutim da i Pavić sklanja »priloge«, tj. rabi ih kao participe, pa ima »činećih« za $\delta \rho \omega ́ v \tau \omega v$ i »imajući« za éxoúonc. Potonji međutim rabi u nominativu jednine muškoga roda, pa činjenica da je posrijedi particip, dakle

\footnotetext{
${ }^{29}$ Vidi o tome potanje Bojan MAROTTI, Tri Lászlóova prijevoda Zaziva Muze u Ilijadi, Filologija, 74 (2020) 49-73, posebice 61-63. Također u: Bojan MAROTTI (gl. ur.), Lučar cijelosti. Zbornik radova posvećen 95. rođendanu prof. dr. sc. Bulcsúa Lászlóa, Zagreb, Hrvatska sveučilišna naklada - Matica hrvatska - Hrvatsko filološko društvo - Društvo mađarskih znanstvenika i umjetnika u Hrvatskoj, 2020, 255-274, posebice 267-270.

${ }^{30}$ Jednom me je prilikom pokojni profesor Vladimir Vratović, videći da je grčku riječ oủ $\sigma i ́ \alpha$ jedan naš prevoditelj na hrvatski »preveo« riječju supstancija, pomalo u šali zapitao: »Pa što je uopće preveo?«

${ }^{31}$ Marković, Razvoj i sustav obćenite estetike..., 1903, 96-97.
} 
pridjev, a ne prilog, nije toliko vidljiva (»čin [...] imajući« = »čin [...] koji ima«). I

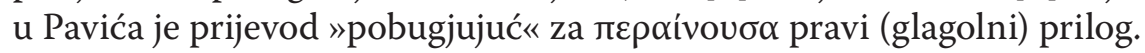

Kažem da je zanimljivo da Pavić sklanja glagolne »priloge«, no moglo bi se reći da ih »još sklanja«, te 1869., kao što »još piše« tvorbenim pravopisom (npr. "pjesničtva«), ali da »već rabi« troslov ije za zapis sljednika jata u dugim slogovima, čime postupno napušta načela Zagrebačke škole (npr. zapis sljednika jata u dugim slogovima dvoslovom ie), te pristupa »taboru«, iliti »okolu«, hrvatskih vukovaca. ${ }^{32}$ Njima će u potpunosti pristupiti u idućim godinama, kao što pokazuje spomenuti sukob 1877. oko pravopisa.

Što se pak tiče navedenih glagolnih "priloga«, nije tako da se oni ne mogu sklanjati jer su prilozi, nego se najprije propiše njihova nesklonidba, pa se zatim proglase prilozima. Naime, svi su oni sklonljivi, ${ }^{33}$ pa bismo primjerice za glagol biti imali ovako: dionik nesvršeni - sûćí, sûćā, sûćē; dva dionika svršena: sadašnji - budući, buduća, buduće, i prošli - bivši, bivša, bivše; te dionik gotovi bio, bila, bilo. Evo kako izgleda sklonidba dionika nesvršenoga u jednini (onoga kojim je jedino moguće, a i kojim treba prevoditi grčki particip prezenta glagola

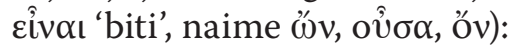
N. sûći
sûća
sûcé
G. sûcéga
sûcée
sûcéga
D. sûcému
sûćōj
sûcému
A. sûcí, sûćéga
sûću
sûcé
V. sûći
sûća
sûcé
L. (o) sûcéem
(o) sû́cój
(o) sûćèm
I. (sa) sûcím
(sa) sûcóom
(sa) sûcím

No rázlīkā se između Pavićeva i Markovićeva prijevoda nađe još poprilično.

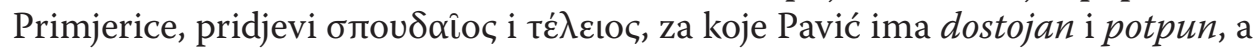
Marković ozbiljan i dovršen. Ili imenica ě $\lambda \varepsilon o c$, koju Pavić prevodi riječju saža-

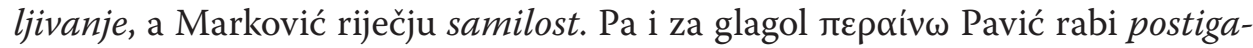
vati, postigavam, a Marković postizati, postižem, dočim za imenicu ỏr $\alpha \gamma \gamma \varepsilon \lambda i ́ \alpha$ Pavić ima pripovijest, a Marković pripoviedajući način. No imenicu фóßoç i jedan i drugi prevode hrvatskom riječju strah (a tako je i u svim ostalim prijevodima, uključujući i Đurićev). ${ }^{34}$ Ne razlikuju se $k$ tomu ni prijevodi imenica

\footnotetext{
${ }^{32}$ Valja podsjetiti da je dvije godine prije, tj. 1867., Petar Budmani objavio prvu »vukovsku« hrvatsku gramatiku, tj. gramatiku u kojoj se opisuje »vukovski sustav« kao onaj koji bi u hrvatskom trebalo prihvatiti kao književni jezik (ili kao uzorni sustav), a koji u razlici spram hrvatskoga (lingua croata - to je književni jezik, dotično uzorni sustav, koji je promicala Zagrebačka škola), zove srpsko-hrvatskim (lingua serbo-croata) [vidi Petar BUDMANI, Grammatica della lingua serbo-croata (illirica), Vienna, A spese dell' autore, 1867].

${ }^{33}$ I sa stajališta povijesti jezika gledano - bili su sklonljivi. To je pak činjenica u svjetlu koje se postupak hrvatskih vukovaca pokazuje još poraznijim.

${ }^{34}$ Vidi ARISTOTEL, O pesničkoj umetnosti, preveo s grčkog i sastavio registar imena dr. Miloš N. Đurić, 3. dop. izd., Beograd, Kultura, 1955. Taj je srpski prijevod u određenim razdobljima,
} 


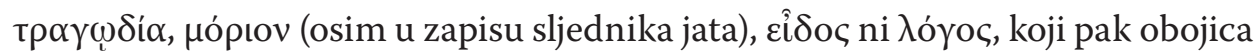
prevode hrvatskom otpovjednicom govor.

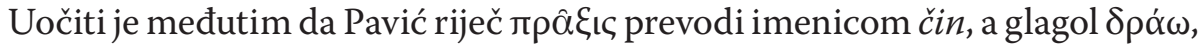
od čega je $\delta \rho \hat{\alpha} \mu \alpha$, glagolom činim (particip $\delta \rho \omega ́ v \tau \omega \nu$ 'činećih'), što bi značilo

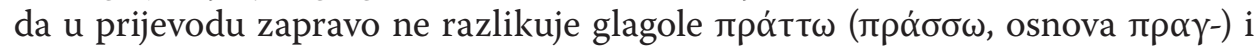
$\delta \rho \alpha ́(\omega$, za razliku od Markovića, koji ima radnja i djelujem ('djelujućih'). To je pojava koja bi se, s jezikoslovnoga stajališta, mogla nazvati gubitkom raznolikosti (u prijevodu). Bitno je pri tome razumjeti da je manje važno koji ćemo od tih dvaju glagola prevesti kojom riječju (jer oba znače i 'radim' i 'djelujem', a i 'činim'), u smislu raspre koji od njih što »doista« znači, ali je u prijevodu bitno održati uzajamne odnose, tj. njihovu »dinamiku«, jer ako se rabe dva različita glagola, onda treba i prevesti dvama različitim glagolima (prema već spomenutome načelu »isto istim, različito različitim«). A odabir hrvatskih glagola utječe potom i na prijevod imenice $\pi \rho \hat{\alpha} \xi ı$. $^{35}$

Navedene je razlike moguće prikazati u ovakvoj preglednici:

\begin{tabular}{|c|c|c|}
\hline Grčki nazivak & Pavić & Marković \\
\hline$\mu i ́ \mu \eta \sigma \mathrm{t \varsigma}$ & oponašanje & priličba (paličba) \\
\hline$\pi \rho \hat{\alpha} \xi ı \varsigma$ & čin & radnja \\
\hline 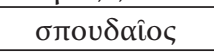 & dostojan & ozbiljan \\
\hline 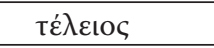 & potpun & dovršen \\
\hline$\delta \rho \alpha ́ \omega$ & činim & djelujem \\
\hline$\dot{\alpha} \pi \alpha \gamma \gamma \varepsilon \lambda i ́ \alpha$ & pripovijest & pripoviedajući način \\
\hline 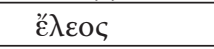 & sažaljivanje & samilost \\
\hline$\pi \varepsilon \rho \alpha i ́ v \omega$ & postigavam & postižem \\
\hline 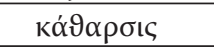 & čišćenje & pročistba \\
\hline$\pi \alpha \dot{\vartheta} \eta \mu \alpha$ & afekt & čuvstvo \\
\hline фóßos & strah & strah \\
\hline
\end{tabular}

posebice pedesetih, šezdesetih, pa i sedamdesetih godina prošloga stoljeća, imao znatna utjecaja i u Hrvatskoj.

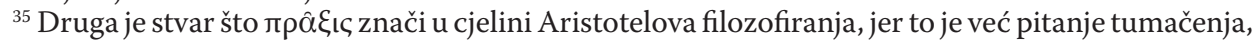
ili interpretacije njegove filozofije. Tako bi se, primjerice, oslanjajući se na neka mjesta u

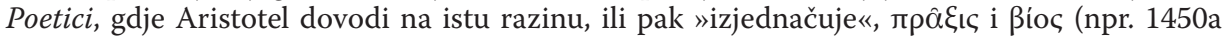
16-17), $\mu$ í se odlučimo za takav prijevod) života, te bismo, zajedno s Maxom Kommerellom, jednim od najboljih tumača Aristotelove Poetike i njegove teorije tragedije, mogli reći da $\mu$ í znači 'prikazivanje zbivanja života' (Kommerell veli Lebensvorgang) [vidi Max KOMMERELL, Lessing und Aristoteles. Untersuchung über die Theorie der Tragödie, Frankfurt am Main, Vittorio Klostermann, 1940, 62; usp. Marotti, Poimanje tragedije iz duha hamartije, u: Švacov, Antička dramaturgija. Antropografija antičke drame..., 428 (ali i cijelo poglavlje Kako prevesti

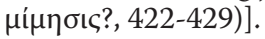




\section{Zaključak}

Kada danas čitamo oba prijevoda, a posebice ako čitamo u cjelini i Pavićev prijevod Poetike i Markovićevu Estetiku, lako se može steći dojam da nam je Pavićev prijevod, premda je stariji, u određenome smislu bliži (izuzmemo li možda glagol postigavati, postigavam). No kako se objašnjava ta naoko protusmislena činjenica, protusmislena sa stajališta uobičajenoga shvaćanja jezika, kada se smatra kako se »jezik razvija«, da nam je ono što je starije, što je objelodanjeno 1869., po mnogočem bliže nego ono što je novije, što je objavljeno 1903.? Pa upravo time što je Marković pripadao onoj školi koja je u bitki oko (književnoga) hrvatskoga jezika - »izgubila«. A to je sustav koji je bio, kako se kaže, »norma« u drugoj polovici (devetnaestoga) stoljeća. Tako su naime pisali klasici hrvatske književnosti: Šenoa, Kovačić, Gjalski. To je taj sustav koji se može nazvati »bilježito« hrvatskim, »markirano« hrvatskim, čime se - tim pojmom koji su promicali pripadnici Praškoga jezikoslovnoga kruga - želi reći da je to sustav za koji nitko nigdje ne može ni pomisliti, a kamoli ustvrditi, da bi mogao pripadati komu drugomu, ili biti štogod drugo, osim hrvatski. ${ }^{36}$

Tijekom povijesti hrvatske filozofije hrvatski su filozofi pisali različitim inojezičnim sustavima, recimo latinskim i talijanskim, a danas sve više pišu engleskim. Kako stvari stoje, sva je prilika da će to u (bliskoj) budućnosti i prevladati. Stoga se ne bi trebalo iznenaditi bude li uskoro tkogod komu gdjegdje u čudu rekao recimo ovako: »Zamisli ti, bilo je u toj zemlji i takvih čudaka koji su pisali jezikom hrvatskim!« Da, pitanje je samo hoće li taj netko biti svjestan da je među onima koji su pisali hrvatski, kao zacijelo jedan od prvih koji je pisao bilježito hrvatskim sustavom, a ruku na srce - istodobno i jedan od posljednjih, bio upravo Franjo pl. Marković.

\footnotetext{
${ }^{36} \mathrm{O}$ pojmu bilježitosti (tj. markiranosti, engleski markedness) vidi Bulcsú LÁSZLÓ, Općitbena bilježitost pri odredbi srbštine i hrvatštine, u: Marin ANDRIJAŠEVIĆ, Lovorka ZERGOLLERNMILETIĆ (ur.), Jezik i komunikacija, Zagreb, Hrvatsko društvo za primijenjenu lingvistiku, 1996, 430-451, posebice 430-432; usp. također Bojan MAROTTI, »Podlagajuchiega naçina urime doscasto « u slovnici Tome Babića Prima grammaticae institutio, u: Alojz JEMBRIH (gl. ur.), Zbornik o Tomi Babiću, Šibenik - Zagreb, Gradska knjižnica »Juraj Šišgorić« Šibenik Hrvatski studiji Sveučilišta u Zagrebu, 2002, 133-164, posebice 148-149.
} 


\section{Bojan Marotti* \\ On Pavićs and Marković's Translation of Aristotle's Definition of Tragedy}

Summary

One of the most famous sentences in the whole history of aesthetics, even in the whole history of philosophy, Aristotle's definition of tragedy (or odredaj, as Franjo Marković translated the term definition), in the history of Croatian philosophy and philology has been translated several times. There are ten versions, if we take into consideration, besides the entire translations of Aristotle's Poetics, some other works, like various histories of (Greek) philosophy, or histories of literary theories and aesthetics, because in those works, within the interpretations of Aristotle's philosophy of art, his definition of tragedy is always considered, and its translation is given very often. The translators are these: Pavić (1869), Kuzmić (1902 and 1912), Marković (from his book The Development and the System of General Aesthetics, 1903), Bazala (from vol. I of his History of Philosophy, 1906), Šanc (from vol. I of his History of Philosophy, 1942), Šamšalović (from Croatian translation of Lessing's Hamburg Dramaturgy, 1950), Dukat (1978 and 1983), and Švacov (from his book Antique Dramaturgy, 2014). Đurić's Serbian translation of Aristotle's Poetics $\left({ }^{3} 1955\right)$ must be taken into account too, because its influence, during some periods of Croatian recent history, was considerable. In the paper, which compares Pavić's and Marković' translation, the specific selection of the Croatian equivalents for the basic Greek terms is discussed, as well as the entire definition, because both, the selected Croatian words and the very »structure« of the Croatian sentence, always show translator's understanding of Aristotle's conception of tragedy, and usually his comprehension of Aristotle's philosophy of art as a whole.

Key words: Aristotle's definition of tragedy, Franjo Marković, Armin Pavić, (philosophical) terminology, tragedy.

(na engl. prev. Bojan Marotti)

\footnotetext{
* Bojan Marotti, PhD, Institute for the History and Philosophy of Science, Croatian Academy of Sciences and Arts, Zagreb; Address: Ante Kovačića 5, HR-10000 Zagreb, Croatia; E-mail: bojan.marotti@zg.t-com.hr.
} 